\title{
COVID-19 Salgınının İcra ve İflâs Hukuku Alanına Etkileri
}

\author{
Murat Atalı* (1), Ersin Erdoğan** (1)
}

Öz

Dünya Sağılık Örgütü tarafindan pandemi ilan edilen COVID-19 salgını, ülkemizde ve dünya genelinde ekonomik faaliyetlere önemli ölçüde zarar vermiştir. Ekonomik hayatın durma noktasına gelmesi, bireylerin daha önce üstlenmiş oldukları edimlerini yerine getirmeleri konusunda çok büyük zorluklar, hatta imkansızlıklara sebebiyet vermiştir. Ülkemizde salgının yaratacağı ekonomik zorlukların bireylerin mahvına sebebiyet vermemesi amacıyla, takip hukuku açısından birtakım tedbirler alınmıştr. İlk olarak 2279 sayılı Cumhurbaşkanlığı Kararı ile İcra ve íflâs Kanunu'nun 330'uncu maddesinde düzenlenen fevkalade tatil kurumuna işlerlik kazandırılmış, daha sonra ise 7226 sayılı Kanun ile bir bütün olarak cebri icra faaliyetlerinin durdurulması öngörülmüştür. İşbu çalışmada, takip hukuku açısından alınan tedbirler ve bunların hukuki sonuçları üzerinde ele alınmaktadır. Bu çerçeve, takip hukukuna ilişkin süreler ile icra ve iflâs takipleri ile takip işlemleri açııından alınan tedbirler ve yarattğı sorunlar incelenmiştir. Kanun koyucu, bir bütün olarak takip hukukuna ilişkin bütün sürelerin durmasını düzenlemiştir. Bu noktada sürelerin taraflar veya icra ve iflâs daireleri açısından düzenlenmiş olması arasında bir ayrım yapılmamıştı. Ayrıca kanun koyucu hem cüz'i icra takiplerinin hem de iflâs takiplerinin yapılmasının önüne geçmiştir. Kanun tarafindan belirlenen durma süresi boyunca yeni icra veya iflâs takibi başlatllamayacağı gibi daha önce başlatılmış olan takipler de duracaktır. Ayrıca kanun koyucu intiyati haciz kararlarının da icra ve infazını da durma süresi boyunca engellemiştir. 7226 sayılı Kanun ile konkordato açısından ortaya çıkan sorunlar da ele alınmıştır.

\author{
Anahtar Kelimeler \\ COVID-19, İcra hukuku, Fevkalade tatil, Takiplerin durması
}

\section{The Impact of COVID-19 on Enforcement and Bankruptcy Law}

\begin{abstract}
The COVID-19 outbreak, which was declared a pandemic by the World Health Organization in March, has significantly damaged economic activities in Turkey and worldwide. Most economic activities have stopped or slowed down because of this pandemic. This situation has caused enormous difficulties and impossibilities for individuals to fulfill the obligations they had previously undertaken. These economic difficulties may economically destroy individuals. Therefore, to help individuals cope with these difficulties, some measures have been taken regarding Enforcement and Bankruptcy Law. First, with the Presidential Decree numbered 2279 regulated in article 330 of the Enforcement and Bankruptcy Law, the extraordinary suspension institution has entered into force. All mandatory execution processes have stopped as per Law 7226. In this paper, measures undertaken regarding Enforcement and Bankruptcy Law and their legal consequences are discussed. Moreover, possible problems are discussed, and the measures taken with respect to the periods in the Enforcement and Bankruptcy Law have been explained. In addition, all enforcement and bankruptcy proceedings have been stopped during this pandemic period. Individuals are not allowed to commence new proceedings. Here, the paper also examines the measures taken regarding the arrest orders and concordat proceedings.
\end{abstract}

\section{Keywords}

COVID-19 Outbreaks, Measures taken regarding Enforcement and Bankruptcy Law, Suspension of proceedings

* Sorumlu Yazar: Murat Atalı (Prof. Dr.), İstanbul Üniversitesi, Hukuk Fakültesi, Medeni Usûl ve İcra-i̇fâs Hukuku Anabilim Dalı, İstanbul, Türkiye. E-posta: muratataliistanbul.edu.tr ORCID: 0000-0003-0279-365X

** Ersin Erdoğan (Doç. Dr.), Ankara Yıldırım Beyazıt Üniversitesi, Hukuk Fakültesi, Medeni Usûl ve İcra-İflâs Hukuku Anabilim Dalı, Ankara, Türkiye. E-posta: eerdogan@ybu.edu.tr ORCID: 0000-0002-3401-940X

Atıf: Atali M, Erdogan E, “COVID-19 Salgınının İcra ve İflâs Hukuku Alanına Etkileri” (2020) 78(2) İstanbul Hukuk Mecmuası 395. https://doi.org/10.26650/mecmua.2020.78.2.0005 


\section{Extended Summary}

With the emergence of the COVID-19 pandemic, governments have undertaken several measures involving legal precautions to provide economic protection to individuals and entrepreneurs. On March 22, 2020, the Turkish government declared an "extraordinary recess" for all enforcement and bankruptcy proceedings with the decree numbered 2279. However, this decree was not sufficient to solve the many problems regarding the periods. All substantial prescriptions and limitation periods are to continue. Consequently, the Turkish Grand National Assembly passed a new law numbered 7226 to provide measures for all areas of law, including enforcement and bankruptcy. The article is as follows:

"The periods specified in the Execution and Bankruptcy Law No. 2004 and the periods specified in other laws related to the execution and bankruptcy proceedings, and the periods determined by the judge or enforcement and bankruptcy offices within the scope of these laws; except for the execution proceedings related to exspouse and child support receivables, all enforcement and bankruptcy proceedings, party transactions and proceedings, initiating new enforcement and bankruptcy proceedings, transactions regarding the enforcement and execution of provisional arrest order shall, from March 22, 2020 (including this date), stop until 30/4/2020 (including this date)."

With the Presidential Decree numbered 2480, the final date has been extended until June 15, 2020.

According to provisional article 1 of the Code subpara. $b$, the following measures have been taken regarding Enforcement and Bankruptcy Law:

First, the Code provides relief to individuals in terms of periods. All periods regulated in the Turkish Code of Enforcement and Bankruptcy shall stop from March 22 to June 15, 2020. Furthermore, between these dates, all periods determined by the judge or enforcement and bankruptcy offices within the scope of Enforcement and Bankruptcy Law shall stop. Thus, if the deadlines are to expire within or less than 15 days as of the start date (June 15) of the suspension period, 15 days of extension will be provided.

Second, all enforcement and bankruptcy proceedings shall stop from March 22 to June 15,2020 . They are suspended and will stay as they were before March 22, 2020. In addition, individuals are not allowed to commence new enforcement and bankruptcy proceedings during this period.

Third, parties shall not conduct any transactions regarding enforcement and bankruptcy proceedings. For example, they may not request arrest or sale of arrested 
assets. The enforcement and bankruptcy offices shall arrange a new sale date without a new request of parties at the end of this period if the date of sale has been decided between March 22 and June 15,2020. The sale announcements will only be conducted electronically, and there shall not be any demand of expense for these announcements. However, we argue that it can be paid to the creditor if the debtor pays their debts directly to enforcement offices. Therefore, the suspension period shall not stop the voluntary payments to the creditor. The enforcement offices must accept voluntary payments. Otherwise, it would be considered unproportional limitation for parties to access their rights. Similarly, the enforcement offices must accept and do what is required by parties if the parties reach any agreements regarding enforcement proceedings.

Fourth, parties may request for provisional arrest orders during this period. Nevertheless, they shall not be enforced and executed until June 15, 2020.

Finally, the consequences of the respites of concordat regarding creditor and debtor will be maintained during this period. This formulation may create some confusion because during the concordat process, some parties may initiate new enforcement proceedings. However, we argued that the consequences of concordat regarding the creditor and their right to commence enforcement proceedings must also be suspended during this period. 


\section{COVID-19 Salgınının İcra ve İflâs Hukuku Alanına Etkileri}

\section{Giriş}

11.03.2020 tarihinde Dünya Sağlık Örgütü tarafından pandemi haline geldiği belirtilen COVID-19 küresel salgını, ülkemizi de olumsuz etkilemiş, bu çalışmanın hazırlandığ1 tarihte yaklaşık 200.000 kişi bu hastalığa yakalanmış, 5.000 kişi ise hayatını kaybetmiştir. Bu süreçte haziran ayına kadar çeşitli tarihlerde ve yerlerde, farklı kapsamlarda sokağa çıkma yasakları uygulanmış ve insanlara evde kalmaları salık verilmiştir. Bu denli kapsamlı tedbirlerin ülke ekonomisini olumsuz etkilememesi düşünülemez. Ticari hayatın neredeyse durma noktasına geldiği böyle bir dönemde, bireylerin daha önce üstlendikleri edimlerini ifa edemedikleri için cebri yaptırımlara tabi kılınması, onların ekonomik olarak mahvına sebep olacak ve netice itibariyle ortaya çıkacak toplam ekonomik zarar, daha büyüyecektir. İnsanların hayatta kalmak için tedbirler aldığı bu dönemde, kanun koyucu da hukuki açısında birtakım düzenlemeler yapma gereği hissetmiş, evvela 2279 sayılı Cumhurbaşkanlığı Kararnamesi ile icra ve iflâs takipleri açısından İcra ve İflâs Kanunu'nun 330'uncu maddesi uyarınca fevkalade tatil kararı alınmış ve ayrıca ilave birtakım tedbirler düzenlenmiştir. Bunu müteakip 7226 sayılı Bazı Kanunlarda Değişiklik Yapılmasına Dair Kanun'un Geçici 1'inci maddesi ile hem yargılamalar hem de icra takipleri açısından kapsamlı tedbirler alınmıştır. Bu çalışmada söz konusu düzenlemeler uyarınca alınan tedbirler icra ve iflâs hukuku açısından değerlendirilmektedir.

\section{2279 Sayılı Cumhurbaşkanlığı Kararı ile Alınan Tedbirler}

İcra ve İflâs Kanunu'nun 330'uncu maddesine göre salgın hastalık, umumi bir musibet veya harb halinde Cumhurbaşkanı karariyle memleketin bir kısmında veya bazı iktisadi zümreler lehine muayyen bir müddet için icra takipleri durdurulabilir. İşte 22.03.2020 Tarih ve 31076 Sayılı Resmî Gazete'de yayınlanan 2279 Sayılı Cumhurbaşkanlığı Kararı ile İcra ve İflâs Kanunu'nun 330'uncu maddesine dayalı olarak COVID-19 salgın hastalığının ülkemizde yayılmasını önlemek amacıyla alınan tedbirler kapsamında; bu Kararın yürürlüğe girdiği tarihten 30/4/2020 tarihine kadar, nafaka alacaklarına ilişkin icra takipleri hariç olmak üzere,

- yurt genelinde yürütülmekte olan tüm icra ve iflâs takiplerinin durdurulmasına ve

- bu çerçevede taraf ve takip işlemlerinin yapılmamasına,

- yeni icra ve iflâs takip taleplerinin alınmamasına ve

- ihtiyati haciz kararlarının icra ve infaz edilmemesine

karar verilmiştir. Söz konusu düzenleme incelendiğinde, fevkalade tatilin uygulanacağı coğrafi alan ve belirli iktisadi zümreler açısından bir sınırlama 
getirilmediği görülmektedir. Buna göre, karar ile belirlenen 30.04.2020 tarihine kadar nafaka alacakları hariç olmak üzere bütün icra ve iflâs takipleri durdurulmuş, yeni takip de başlatılamaması kabul edilmiştir. Ayrıca ayrım yapılmaksızın bütün taraf ve takip işlemlerinin duracağı belirtilmiştir. Karar uyarınca ihtiyati haciz kararı alınmasının önünde bir engel bulunmasa da bu kararın icra ve infaz edilmesinin de önüne geçilmiştir. Böylece Kararın Resmî Gazete'de yayınlandığı 22.03.2020 tarihi ile 30.04.2020 tarihleri arasında takip işlemleri açısından öngörülen süreler işlemeyecektir.

Bu noktada, muhtemel bir karışıklı̆ğ giderilmesinde fayda vardır. Fevkalade hallerde tatil kurumu (İK m. 330) ile fevkalade mühlet (İIK m. 317-329) amaçları ve buna karar verecek makamlar itibariyle benzeşse de nitelik ve sonuçları itibariyle birbirinden farklıdır. Fevkalade mühletin söz konusu olduğu hallerde Cumhurbaşkanlığı kararı yalnızca fevkalade mühlete ilişkin hükümlerin yürürlüğe konulduğunu belirtir, hangi borçluların bundan istifade edebilecekleri ise icra mahkemesi kararı ile ayrı ayrı tespit edilir. Fevkalade hallerde tatil kurumunda ise karar ile birlikte kapsamda yer alan (coğrafi veya ekonomik zümre olarak) bütün borçlular kendiliğinden istifade eder ${ }^{1} .2279$ sayılı Karar ile fevkalade hallerde tatil kurumuna işlerlik kazandırılmıştır. Ancak İcra ve İflâs Kanunu'nun 330'uncu maddesinde yalnızca "icra takiplerinin" durdurulması düzenlenmişken, 2279 sayılı Karar ile iflâs takipleri de kapsama dahil edildiği gibi yeni takip (icra veya iflâs) yapılması da engellenmiştir. Ayrıca ihtiyati haciz kararlarının da icra ve infaz edilemeyeceği belirtilmiştir. Kanunda açıkça bir dayanağı bulunmayan söz konusu sınırlamaların Cumhurbaşkanlığı Kararı ile getirilebilmesi esasen mümkün değildir. Zira Anayasa'nın 13'üncü maddesinde belirtildiği üzere temel hak ve özgürlükler ancak kanunla sınırlanabilir. Keza Anayasa'nın 104'üncü maddesi uyarınca Cumhurbaşkanlığı kararnamesi ile temel hak ve özgürlükler düzenlenemez. Somut durumda, bir Kararname de değil, idari nitelikte bir işlem olan Cumhurbaşkanlığ 1 Kararı söz konusudur². Bireylerin hak arama özgürlüğünün gereği olan icra ve iflâs takiplerinin başlatılmasının durdurulabilmesi, ihtiyati haciz kararlarının icra ve infazının engellenebilmesi için açık bir kanuni düzenlemeye ihtiyaç bulunmaktadır. Ancak aşağıda inceleneceği üzere 7226 sayılı Kanun'un Geçici 1'inci maddesi ile bu tartı̧̧ma önemini yitirmiştir.

Fevkalade hallerde tatil kararı alınması üzerine Kanunda yalnızca takiplerin duracağı düzenlenmiş, hem icra hukukuna özgü sürelerin hem de maddi hukuka ait zamanaşımı ve hak düşürücü sürelerin akıbeti konusunda bir hükme yer verilmemiştir. Keza 2279

Ejder Yılmaz, 'Olağanüstü Durumlarda Borçlulara Süre Verilmesi ve İcra Takiplerinin Durdurulması' (1977), IX(1), BATIDER 153, 178.

Cumhurbaşkanlığı Kararnamesi ile Cumhurbaşkanlığı Kararı arasındaki farklar için bkz Şeref İba ve Yasin Söyler, 'Yeni Hükümet Sisteminde Cumhurbaşkanlığı Kararnamesi ile Cumhurbaşkanlığı Kararının Nitelik Farkı ve Hukuki Sonuçları' (2019), 36(1), Anayasa Yargisı 195, 223. 
sayılı Kararda da bu yönde bir açıklık bulunmamaktadır. Ancak yukarıda belirtildiği üzere amaçlarının müşterek olması sebebiyle fevkalade mühlete ilişkin hükümlerin, niteliğine uygun düştüğü ölçüde fevkalade hallerde tatil kurumu açısından da kıyasen uygulanabilmesi gerekir. Bu çerçevede, İcra ve İflâs Kanunu'nun 323'üncü maddesinin ikinci fikrasinda düzenlenen Kanunun 106, 150/e, 156, 206, 278, 279 ve 280'inci maddelerinde öngörülen sürelerin tatil halinde de durduğu kabul edilmelidir ${ }^{3}$. Buna karşılık fevkalade hallerde tatil kararı üzerine maddi hukuka ait zamanaşımı süreleri ile hak düşürücü sürelerin durması söz konusu değildir ${ }^{4}$. Ancak aşağıda inceleneceği üzere 7226 sayılı Kanun'un Geçici 1'inci maddesi ile bu tartışma önemini yitirmiştir.

2279 sayılı Karar yalnızca icra ve iflâs takipleri ile ihtiyati haciz kurumu açısından alınan tedbirleri düzenlemektedir. Hukuk davaları ve yargılamaların işleyişi noktasında bir tedbir içermemektedir.

\section{7226 Sayılı Kanun ile Takip Hukuku Açısından Alınan Tedbirler}

26.03.2020 tarihinde Resmî Gazete'de yayınlanan 7226 sayılı Bazı Kanunlarda Değişiklik Yapılmasına Dair Kanun'un Geçici 1'inci maddesi, salgının yol açacağı hak kayıplarının önüne geçilebilmesi amacıyla, maddi hukuka ait süreler yanında hem icra ve iflâs hukukuna hem de yargılama hukuku alanına dönük tedbirler içermektedir. Söz konusu 7226 say1lı Kanun’un Geçici 1'inci maddesinin birinci fikrasının a bendinde yargılama hukuku açısından bazı sürelerin durması tedbir olarak düzenlenmekteyken $\mathrm{b}$ bendinde ise icra takiplerine özgü tedbirler yer almaktadır.

İcra hukukuna özgür tedbirler açısından 7226 sayılı Kanun'un Geçici 1'inci maddesi ile özellikle İcra ve İflâs Kanunu'nun 330'uncu maddesini uygulamaya koyan 2279 sayılı Cumhurbaşkanlığ kararı ile zaman bakımından uygulanma sorunu tartışması doğmaktadır ${ }^{5}$.

2279 sayılı Cumhurbaşkanlığı kararının idari nitelikte olması, 7226 sayılı Kanun'un uygulama zamanının söz konusu karar ile aynı tarihte olacak şekilde geçmişe yürütülmüş olması, 7226 sayılı Kanun ile getirilen düzenlemenin hem

Baki Kuru, İcra ve Iflas Hukuku El Kitabı (2. Bası, Yetkin 2013) 1583; Taylan Özgür Kiraz, 'Fevkalâde Hallerde Mühlet ve Tatil’ (2000), 2, Manisa Barosu Dergisi 7, 13; Y1lmaz, (n 3) 182.

4 Öğretide fevkalade tatil kararı üzerine maddi hukuka ait zamanaşımı sürelerinin de duracağı belirtilmekteyse de buna dair bir pozitif dayanak bulunmamaktadır. Örneğin Kuru, İcra ve İflâs Kanunu'nun fevkalade mühlete ilişkin 323 'üncü maddesinin ikinci fikrasının kıyasen uygulanması suretiyle zamanașımı ve hak düşürücü sürelerin duracağından bahsetmektedir ki ilgili madde yalnızca icra hukukuna özgü bazı sürelerin durmasını öngörmektedir. Kuru, (n 5) 1583. Fevkalade mühlet halinde zamanaşımı ve hak düşürücü sürelerin duracağına dair bir hüküm yer almamaktadır. Takip başlatılmasının mümkün olması karşısında, böyle bir ihtiyacın bulunduğundan da söz edilemez. Fevkalade tatil hallerinde zamanaşımı ve hak düşürücü sürelerin duracağı yönünde ayrıca bkz Hakan, Pekcanıtez, '2279 sayılı Cumhurbaşkanı (Fevkalâde Mühlet) Kararı ile 7226 Sayılı Kanunun Geçici 1. Maddesinin Birlikte Değerlendirilmesi', (Lexpera Blog, 28.03.2020) https://blog.lexpera.com. tr/2279-sayili-karar-ile-7226-sayili-kanunun-birlikte-degerlendirilmesi Erişim Tarihi 18 Haziran 2020.

Oğuz Atalay ve Muhammet Özekes, '7226 Sayılı Kanun ile İcra ve İflâs Kanunu m. 330 Hükmünü Uygulayan Cumhurbaşkanlığı Kararı (2279 Sayı1ı) Çerçevesinde Ortaya Çıkan Bazı Sorular ve Tartışmalara Cevaplar’, (Lexpera Blog, 27.03.2020) https://blog.lexpera.com.tr/7226-sayili-kanun-ile-cumhurbaskanligi-karari-neticesinde-ortaya-cikan-sorunlar Erişim Tarihi 18 Haziran 2020 
sonraki hem özel hem de üstün norm olması birlikte değerlendirildiğinde, 2279 sayılı Cumhurbaşkanlığı kararının (fiilen uygulandığ 22.03.2020 ila 26.03.2020 tarihleri hariç olmak üzere) uygulama alanının bulunmadığının kabulü gerekir ${ }^{6} . \mathrm{Bu}$ çerçevede, işbu çalışmada takip hukukuna özgü tedbirler değerlendirilirken 7226 sayılı Kanun'un Geçici 1'inci maddesi dikkate alınmıştır.

7226 sayılı Kanun'un Geçici 1'inci maddesinin birinci fikrasının b bendinde, takip hukuku açısından alınan tedbirler özel olarak düzenlenmektedir. Buna göre, 9/6/1932 tarihli ve 2004 sayılı İcra ve İflas Kanunu ile takip hukukuna ilişkin diğer kanunlarda belirlenen süreler ve bu kapsamda hâkim veya icra ve iflâs daireleri tarafindan tayin edilen süreler; nafaka alacaklarına ilişkin icra takipleri hariç olmak üzere tüm icra ve iflâs takipleri, taraf ve takip işlemleri, yeni icra ve iflâs takip taleplerinin alınması, ihtiyati haciz kararlarının icra ve infazına iliş̧kin işlemler 22/3/2020 (bu tarih dâhil) tarihinden, itibaren 30/4/2020 (bu tarih dâhil) tarihine kadar durur.

7226 sayılı Kanun'un Geçici 1'inci madde ile Cumhurbaşkanı'na verilen yetki kapsamında, 30.04.2020 Tarih ve 31114 Sayılı Resmî Gazete'de yayınlanan 2480 Sayılı Cumhurbaşkanlığı Kararı ile durma süresi, 4734 sayll Kamu İhale Kanununda öngörülen zorunlu idari başvuru yoluna ilişkin süreler hariç olmak üzere 01.05.2020 tarihinden itibaren 15.06.2020 tarihine kadar (salgın hastalığın yayılma tehlikesinin daha önce ortadan kalkması halinde yeniden değerlendirilmek üzere) uzatılmıştır.

Söz konusu düzenleme dikkate alındığında, takip hukukuna özgü alınan tedbirleri üç ayrı başlık altında incelemek mümkün görünmektedir: Süreler, takipler ve takip işlemleri, ihtiyati haciz kararları.

\section{A. Takip Hukuku Açısından Süreler Yönünden Alınan Tedbirler}

7226 sayıl1 Kanun'un Geçici 1'inci maddesinin birinci fikrasının b bendinde, İcra ve İflas Kanunu ile takip hukukuna ilişkin diğer kanunlarda belirlenen süreler ve bu kapsamda hâkim veya icra ve iflâs daireleri tarafindan tayin edilen sürelerin 22.03.2020 tarihi itibariyle durması öngörülmüştür. Buna göre;

- İcra ve İflas Kanunu'nda düzenlenen (bütün) süreler

- Takip hukukuna ilişkin diğer kanunlarda belirlenen süreler

- Takip hukukuna ilişkin hâkim tarafindan belirlenen süreler

- Takip hukukuna ilişkin icra veya iflâs daireleri tarafindan belirlenen süreler

\footnotetext{
Atalay ve Özekes, (n 7) https://blog.lexpera.com.tr/7226-sayili-kanun-ile-cumhurbaskanligi-karari-neticesinde-ortayacikan-sorunlar Erişim Tarihi 18 Haziran 2020. Ayrıca bkz Hakan Pekcanıtez ve Evrim Erişir, 'Koronavirüs (Covid-19) Salgınına Karşı Alınan, Medenî Usûl ve İcra-İflâs Hukukunu İlgilendiren Önlemler', (Legal Blog, 03.06.2020) https://legal. com.tr/blog/genel/koronavirus-covid-19-salginina-karsi-alinan-medeni-usûl-ve-icra-iflâs-hukukunu-ilgilendiren-onlemler Erişim Tarihi 18 Haziran 2020; Aziz S. Arslan, 'Covid-19 Salgını Sebebiyle İcra Takiplerine İlişkin Düzenlemelerin Değerlendirilmesi’ (2020), 33(148), TBBD 197, 205.
} 
22.03.2020 tarihi itibariyle durmuştur?.

Örneğin, İcra ve İflas Kanunu'nda düzenlenen;

- Taşınırın teslimine ilişkin icra emrinin gereğinin yerine getirilmesi için öngörülen yedi günlük süre (İ̈K m. 24)

- Çocuk teslimine ilişkin olarak düzenlenen yedi günlük süre (İ̈K m. 25)

- Taşınmazın tahliye ve teslimi için düzenlenen yedi günlük süre (İIK m. 26)

- Para alacaklarına ilişkin icra emrinin gereğinin yerine getirilmesi için düzenlenen yedi günlük süre (İK m. 32)

- İlâma dayanan takipler için öngörülen on y1llık zamanaşımı süresi (IİK m. 39)

- Para ve teminat alacaklarına ilişkin gönderilen ödeme emri uyarınca mal beyanında bulunmak, ödemek veya itiraz etmek için düzenlenen yedi günlük süre (İ̈ m. 60, m. 62)

- Gecikmiş itiraz yoluna başvurmak için engelin kalktığı günden itibaren hesaplanan üç günlük süre (ïK m. 65)

- İtirazın bertaraf edilmesi üzerine mal beyanında bulunmak için öngörülen üç günlük süre (İ̈K m. 75)

- Haciz talep edebilmek için düzenlenen bir yıllık süre (İ̈K m. 78)

- Haciz ihbarnamesine karşı itiraz süresi (İ̈K m. 89)

- İstihkak iddiasında bulunmak için düzenlenen yedi günlük süre (İIK m. 96)

- Satış istemek için düzenlenen altı aylık ve bir yıllık süre (İK m. 106)

- Taşınırların satışı için düzenlenen iki aylık süre (İ̈K m. 112)

- Taşınmazların satışı için düzenlenen üç aylık süre (İ̈K m. 123)

22.03.2020 tarihi itibariyle, 15.06.2020 tarihine kadar durmuştur.

Bu noktada İcra ve İflâs Kanunu'nun 111 'nci maddesince taksitle ödemeye ilişkin sürelerin de açıklığı kavuşturulması gerekir. Borçlu, Kanun'da öngörülen koşullara uygun olmak kaydıyla, alacaklının ve icra dairesinin onayına ya da rızasına ihtiyaç olmaksızın taksitle ödeme teklifinde bulunabilir ve borcunu taksitle ödeyebilir. Kanun'un 111'inci maddesinin en tipik özelliği, burada öngörülen şartlara uygun bir teklifin yapılması halinde alacaklının rızasına gerek olmamasıdır. Kanunda öngörülen şartlara uygun bir taksitle ödeme teklifi alacaklıyı bağlar ve takibe devam edilmesine engel olur. Kanun'un 111'nci maddesinde taksitle ödemenin gerçekleşebilmesi için, borçlunun yeter miktarda malının haczedilmiş olması, alacaklının satıs talebinden evvel borçlunun ilk taksiti peşin ödeyecek şekilde, aydan aya ve toplamda üç ayı

Bu çalışma kapsamı dışında kalmakla birlikte maddi hukuka ilişkin zamanaşımı ve hak düşürücü sürelerin durması 7226 sayılı Kanun'un Geçici 1'inci maddesinin birinci fikrasının a bendinde düzenlenmektedir. Bu çerçevede, maddi hukuka ait süreler açısından fevkalade hallerde tatile ilişkin 2279 sayılı Cumhurbaşkanlığı kararı üzerine yaşanabilecek tartışma, 7226 sayılı Kanun ile ortadan kaldırılmıştır. 
geçmemek üzere ödeme teklifinde bulunması gerekir. Bu çerçevede bir teklif üzerine artık alacaklının veya icra dairesinin kabulü aranmaksızın sonuç doğurur. İcra ve İflâs Kanunu teklif için asgari şartları düzenlemiş̧ir. Borçlunun daha iyi bir teklifinin de (örneğin iki taksitle borcu ödeyeceğini belirtmesi, onbeş günde bir ödeme yapacağını belirtmesi gibi) aynı sonucu doğuracağı tereddütsüzdür. Dolayısıyla, İcra ve İflâs Kanunu yalnızca azami süreleri düzenlemektedir, gerçekte süreyi tespit eden ise borçludur. Keza taksitle ödeme açısından öngörülen bu süreler, aynı zamanda maddi hukuka aittir ${ }^{8}$. Şu hâlde, azami süre kanunda düzenlenmiş olmakla birlikte, taksitlere ilişkin borçlu tarafindan tayin edilen sürelerin 7226 sayılı Kanun'un Geçici 1'inci maddesinin birinci fikrasının $\mathrm{b}$ bendi kapsamında durduğundan söz edilemez'. İcra ve İflâs Kanunu'nun 111'inci maddesindeki şartlar dışında, alacaklı ve borçlunun taksitle ödemeye ilişkin bir sözleşme yapmış olması durumunda, taraflar arasındaki sözleşmede belirlenen sürelerin ise 7226 sayılı Kanun'un Geçici 1'inci maddesinin birinci fikrasının b bendi kapsamında durmadığı şüpheden uzaktır.

Takip hukukuna ilişkin diğer kanunlarda yer alan sürelere ise 7155 sayılı Abonelik Sözleşmesinden Kaynaklanan Para Alacaklarına İliş̧in Takibin Başlatılması Usûlü Hakkında Kanun'da yer alan süreler veya Türk Ticaret Kanunu'nun deniz ticareti kitabında yer alan cebri icraya ilişkin süreler verilebilir.

İcra ve İflâs Kanunu hükümlerine göre icra dairesi tarafından, icranın geri bırakılması kararı getirilmesi için verilen süre (İiK m. 36), depo ve garajlarda ve yediemin olarak kendisine haczedilen malın bırakılmış olduğu üçüncü kişilerde saklanıp da hukuken artık muhafazasına gerek kalmayan malın geri alınması için verilen süre (İ̈K m. 88), yedi veya on günü geçmemek üzere alıcıya verilen süre (İ̈K m. 118 ve m. 130) ile icra mahkemesi hakimince terekenin borca batık olduğu iddiasında bulunan tarafa verilecek süre (İ̈K m. 68) de 22.03.2020 itibariyle (15.06.2020 tarihine kadar) durmuştur.

7226 sayılı Kanun'un Geçici 1'inci maddesinin birinci fikrasının a bendinde, Hukuk Muhakemeleri Kanunu ve usûl hükmü içeren diğer kanunlardaki sürelerin 13.03.2020 itibariyle durduğu düzenlenmiştir. Esasen İcra ve İflâs Kanunu’nda yer alan yargılamaya ilişkin sürelerin de bu kapsamda olması beklenirdi. Ancak, İcra ve İflas Kanunu'nda düzenlenen davalar ve hukuki başvuru yollarına ilişkin sürelerin durması, Geçici 1'inci maddesinin birinci fikrasının b bendinde ayrıca ve özel olarak düzenlendiği için (zira İcra ve İflas Kanunu'nda düzenlenen sürelere genel bir atıf vardır), bu davalar bakımından zikredilen hükmün (b bendinin) dikkate alınması gerekir.

\footnotetext{
Atalay ve Özekes, (n 7) https://blog.lexpera.com.tr/7226-sayili-kanun-ile-cumhurbaskanligi-karari-neticesinde-ortayacikan-sorunlar Erişim Tarihi 18 Haziran 2020.

9 Durma süresi içerisinde borçlunun ödeme yükümlülüğü olmadığı yönünde bkz Pekcanıtez ve Erişir, (n 8) https://legal. com.tr/blog/genel/koronavirus-covid-19-salginina-karsi-alinan-medeni-usûl-ve-icra-iflâs-hukukunu-ilgilendiren-onlemler Erişim Tarihi 18 Haziran 2020.
} 
7226 sayılı Kanun'un Geçici 1'inci maddesinin birinci fikrasının a bendinde sürelerin durmasına ilişkin olarak getirilen ölçüt ile takip hukuku açısından alınan süreler noktasında iki fark bulunmaktadır. İlk olarak, takip hukuku açısından sürelerin durması açısından, durma süresinin başlangıcı farklı düzenlenmiş̧ir. Yargılamalar açısından durma süresi 13.03.2020 tarihinden itibaren başlamakta iken takip hukuku açısından sürenin başlangıcı 22.03.2020 olarak belirlenmiştir. İkincisi, takip hukuku bakımından duracak süreler belirlenirken, bunların "taraflar bakımdan" öngörülmüş olması şartı aranmamış, kanun koyucu İcra ve Iflas Kanunu ile takip hukukuna ilişkin diğer kanunlarda belirlenen bütün sürelerin (ve bu kapsamda hâkim veya icra ve iflâs daireleri tarafindan tayin edilen süreler) duracağını düzenlemektedir. Esasen bu farklılı̆̆ın, süreç içerisinde yapılamayacak işlemler ile de bağlantısı vardır. Kural olarak durma süresi boyunca yargılama faaliyetleri durdurulmuş değildir. Mahkeme usûl işlemlerinin (duruşma, keşif müzakere hariç) yapılmaya devam edilmesi gerektiği gibi, bu süre içerisinde dava açmak, cevap vermek, istinaf ve temyiz yoluna başvurmak gibi taraf usûl işlemlerinin yapılması da mümkündür. Ancak aşağıda inceleneceği üzere icra takipleri açısından hem taraf takip işlemlerinin hem de icra takip işlemlerinin 22.03.2020 itibariyle yapılamayacağı düzenlenmiştir. Bu kapsamda icra takiplerinin (yargılamalardan farklı olarak) durduğundan söz etmek mümkündür. Dolayısıyla duran sürelerin kapsamı bakımından "taraflar bakımından” öngörülmüş olma gibi bir şart, İ́ra ve İflâs Kanunu'nda düzenlenen süreler için geçerli değildir.

Yargılamaya ilişkin süreler bakımından bir ayrım yapılmasının pek çok tartışmaya ve tereddüte yol açacak olmasına rağmen, pozitif düzenleme gereğince yargılamaya ilişkin olmasına rağmen İcra ve İflâs Kanunu'nda düzenlendiği için durma süresinin 22.03.2020 itibariyle başladığı hallerin şu şekilde zikredilmesi mümkündür:

- İcra mahkemesine yapılacak yedi günlük şikâyet süresi

- İcra mahkemesince, duruşma yapılmayacak işlerde, şikâyet hakkında karar vermek için öngörülen on günlük süre

- İcra mahkemesine yapılacak altı aylık itirazın kaldırılması süresi

- Genel mahkemelerde açılacak yedi günlük borçtan kurtulma davası süresi

- Genel mahkemelerde açılacak bir yıllık itirazın iptali davası süresi

- İcra mahkemesinde açılacak istihkak davası süresi

- İcra mahkemesine ihalenin feshi talebinde bulunmak için düzenlenen süreler

- İcra mahkemesine yapılacak sıra cetveline şikâyet başvurusu süresi

- Genel mahkemelerde açılacak sıra cetveline itiraz davası açma süresi

- Genel mahkemelerde açılacak olan tasarrufun iptali davası açılmasına ilişkin düzenlenen bir, iki ve beş yıllık süreler 
İcra ve İflâs Kanunu'nda düzenlenen ve yukarıda yer verilen söz konusu kurumlara ilişkin olarak, yargılama sırasında hâkim tarafindan taraflara verilen süreler de 7226 sayılı Kanun'un Geçici 1'inci maddesinin birinci fikrasının b bendi uyarınca 22.03.2020 tarihi itibariyle durmuştur. Buna karşılık, söz konusu yargılamalar açısından İcra ve İflâs Kanunu'nda düzenlenmeyen ve buna göre hâkim tarafindan tayin edilmeyen süreler açısından 7226 sayılı Kanun'un Geçici 1'inci maddesinin birinci fikrasının a bendinin dikkate alınması gerekir. Yargılamaya ilişkin söz konusu süreler açısından a bendi kapsamında alınan tedbirlerin, $b$ bendinden farklı olarak bireylerin hak arama özgürlüğünü temin amacı gittiği mutlaka dikkate alınmalıdır. Dolayısıyla, İcra ve İflâs Kanunu'nda (veya takip hukukuna ilişkin diğer bir kanunda) düzenlenmeyen yargılamaya ilişkin süreler açısından a bendinin esas alınması, hukuki dinlenilme hakkının da gereğidir. Örneğin, itirazın iptali davasında veya istihkak davasında cevap süresi, aşağıda incelendiği üzere, a bendi kapsamında 13.03.2020 tarihi itibariyle durmuştur. Keza icra mahkemesi kararlarına karşı istinaf kanun yolu süresi de İcra ve İflâs Kanunu'nda düzenlendiğinden, söz konusu süre de 22.03.2020 tarihi itibariyle durmuştur. Buna karşılık, temyiz süresi özel olarak düzenlenmemiş, temyiz incelemesinin Hukuk Muhakemeleri Kanunu'na göre yapılacağı belirtilmiştir (İK m. 364/II). Şu hâlde, icra mahkemesinde gerçekleştirilen yargılamalar üzerine bölge adliye mahkemesince verilen kararlara karş1 temyiz süresi, 7226 say1lı Kanun'un Geçici 1'inci maddesinin birinci fikrasının a bendi kapsamında 13.03.2020 itibariyle durmuştur ${ }^{10}$.

Sürelerin durmasının hukuki sonucu Kanunda ayrıca düzenlenmiş̧ir. Buna göre, durma süresinin başladığı tarih itibarıyla (22.03.2020), bitimine on beş gün ve daha az kalmış olan sürelerin, durma süresinin sona erdiği günü (15.06.2020) takip eden günden başlamak üzere on beş gün uzamış sayılacağ $1^{11}$ öngörülmüştür. Buna göre, 22.03.2020 tarihinden önce işlemeye başlamış süreler, bu tarih itibariyle duracak ve 15.06.2020 tarihi itibariyle kaldığ yerden işlemeye devam edecektir. 22.03.2020 tarihi itibariyle, kalan süre onbeş günden az ise, bu süre 15.06.2020 tarihinden itibaren onbeş gün olarak kabul edilecektir. Şu halde, 22.03.2020 itibariyle sona ermesine onbeş günden az kalmış işlemlerin, 30.06.2020 tarihine kadar yapılabilmesi mümkündür. İcra ve İflâs Kanunu'nda yer alan pek çok sürenin onbeş günden kısa olduğu dikkate alındığında, alınan tedbirler kapsamında işlemin normal durumunda

\footnotetext{
10 Öğretide, 7226 sayılı Kanun'un Geçici 1'inci maddesinin birinci fikrasının b bendinin amacının dikkate alınması gerektiği, kanun koyucunun dava ve hukukî çareleri de içine alacak şekilde icra ve iflâs takip prosedürleri ile diğer muhakeme usûllerini birbirinden ayırmayı amaçladığı, dolayısıyla İcra ve İflâs Kanunu'nda düzenlenen kurumlar açısından bütün sürelerin, diğer kanunlarda yer alsa da b bendi kapsamında olması gerektiği belirtilmiştir. Ancak yazarlar, dava veya hukuki çarenin düzenlendiği yer kriterinin de meseleyi bütünlüğü ile açıklı̆ı kavuşturmadığını belirtmektedir. Görüş için bkz Pekcanıtez ve Erişir, (n 8) https://legal.com.tr/blog/genel/koronavirus-covid-19-salginina-karsi-alinan-medeni-usûl-veicra-iflâs-hukukunu-ilgilendiren-onlemler Erişim Tarihi 18 Haziran 2020.

11 Kanunda yer alan, sürelerin uzamış sayılacağına ilişkin ifadenin tereddüt uyandıracak nitelikte olduğu hakkında bkz Murat Atalı ve Ersin Erdoğan, 'Covid-19 Salgını Sebebiyle Yapılan Düzenlemelerin Medenî Usûl Hukuku Alanına Yansımaları', iç Muhammet Özekes (ed), Covid-19 Salgınının Hukuki Boyutu Hukukun Tüm Alanlarında Değerlendirmeler (1. Bası, Oniki Levha 2020) 48.
} 
yapılması için öngörülen süreden daha uzun bir süre içerisinde gerçekleştirilmesi imkânı yaratılmıştır. Örneğin borçlu 18.03.2020 tarihinde tebliğ edilen ödeme emrine yedi gün içerisinde itiraz edebilirdi. 22.03.2020 tarihi itibariyle süreler durduğu için, esasen borçlunun dört günlük bir süresi kalmaktadır. Ancak mevcut düzenleme sebebiyle borçlu 15.06.2020 tarihinden sonra onbeş gün içerisinde (30.06.2020) tarihine kadar ödeme emrine itiraz edebilir.

\section{B. İcra Takipleri ve Takip İşlemleri Bakımından Alınan Tedbirler}

7226 sayılı Kanun'un Geçici 1'inci maddesinin birinci fikrası uyarınca, 22.03.2020 ila 15.06.2020 tarihleri arasinda;

- Yeni icra veya iflâs takibi başlatılamayacağı,

- Derdest icra ve iflâs takiplerinin duracağı,

- Taraf ve icra takip işlemlerinin yapılamayacağ1

düzenlenmiştir.

\section{1. İcra ve İflas Takipleri Açısından Alınan Tedbirler}

Kanun koyucu hem yeni icra ve iflâs takibi yapılmasını engellemiş hem de mevcut takiplerin duracağını düzenlemiştir. Bu çerçevede kanun koyucu yalnızca nafaka alacaklarını hariç tuttuğundan, nafaka alacağına dayalı olarak başlatılacak takipler hariç, ilâmlı veya ilâmsız, cüzi veya külli herhangi bir takibin başlatılabilmesi veya başlamış olan takibe devam edilebilmesi mümkün değildir. Bu kapsamda doğrudan doğruya iflâs talebinde bulunulabilmesi veya iflâs davası açılabilmesi de söz konusu olmamalidir ${ }^{12}$.

Kanun koyucu yalnızca takiplerin durmasından değil, yeni takip talebi alınmamasını da öngördüğ̈ünden, icra dairesinin alacaklının takip talebini reddetmesi gerekir. Aksi halde, örneğin UYAP üzerinden gönderilen takip talebinin reddine karar verilmemesi halinde, süresiz olarak şikâyet yoluna başvurulabilir ${ }^{13}$. Nafaka alacaklarına ilişkin olarak ise ilâmlı (yoksulluk nafakasında olduğu gibi) veya ilâmsız (tedbir nafakasında olduğu gibi) takip başlatılabilmesi ve başlamış olan takibe devam edilebilmesi mümkündür.

Takip talebinde bulunulmasının engellenmesinin hak arama özgürlüğünü sınırladığı

\footnotetext{
Pekcanıtez ve Erişir, (n 8) https://legal.com.tr/blog/genel/koronavirus-covid-19-salginina-karsi-alinan-medeni-usûl-veicra-iflâs-hukukunu-ilgilendiren-onlemler Erişim Tarihi 18 Haziran 2020.

13 Takip yasağına ilișkin mevcut hüküm, konkordato mühleti içerisinde takip yasağını düzenleyen İcra ve İflâs Kanunu'nun 294'üncü maddesine benzemektedir. Ancak mühlet içerisinde takip yasağına ilişkin söz konusu hüküm, yalnızca icra takip işlemlerinin yapılamaması şeklinde anlaşılmakta, dolayısıyla alacaklının takip talebinde bulunmasının önünde bir engel olmadığı kabul edilmektedir. Bu yönde bkz Sümer Altay ve Ali Eskiocak, Konkordato ve Yeniden Yapılanma Hukuku, (4. Bası, Vedat 2018) 104. 7226 sayılı Kanun'un Geçici 1'inci maddesinin birinci fikrasının b bendinde ise yalnızca icra takip işlemlerinin değil, takibe dair bütün işlemlerin durması öngörüldügünden ve ayrıca yeni icra ve iflâs takip taleplerinin alınmasından açıkça söz edildiğinden, içeriği itibariyle Kanunun 294'üncü maddesinden farklı olduğu anlaşılmaktadır.
} 
şüpheden uzaktır. Bu noktada, Covid-19 salgını nedeniyle alınan tedbirlerin saikleri noktasında, takip hukuku ile yargılama hukuku açısından farklılığa dikkat çekmekte fayda görmekteyiz. Yargılama hukuku açısından alınan tedbirler, esasen bireylerin taraf usûl işlemleri açısından düzenlenen hak düşürücü süreleri kaçırmaları sebebiyle ortaya çıkacak hak kayıplarının önlenmesine yöneliktir. Bu süreçte bireylerin söz konusu işlemleri yapması da engellenmemiştir. Takip hukuku açısından alınan tedbirlerin temelinde ise bireylerin hak kayıplarından ziyade salgının yaratacağ 1 ekonomik gerekçelerin olduğu anlaşılmaktadır. Başka bir anlatımla, takip hukukuna ilişkin alınan tedbirler ile amaçlanan, bireylerin ekonomik olarak mahıvlarının önüne geçmektedir. Nafaka alacaklarının kapsam dışında bırakılması da bu saiki desteklemektedir. Bu nedenle, takip hukuku açısından alınan tedbirlerin kapsamına ilişkin tereddütlerin giderilmesi noktasında bu saikin dikkate alınması önemlidir. $\mathrm{O}$ nedenle, takip hukukuna ilişkin tedbirlerde, esasen hak arama özgürlüğünün sınırlanması ile karşı tarafın ekonomik bütünlüğü dengesinde, ekonomik bütünlüğe önem verdiği görülmektedir. Bu süreçte hem maddi hukuka hem de takip hukukuna ilişkin sürelerin durmuş olması ise hak arama özgürlüğüne getirilen sınırlamanın, hakkın özüne dokunmasına mâni olmaktadır.

Kanun koyucu "tüm" icra ve iflâs takiplerinin durduğunu belirmektedir. Bu kapsamda yeni icra ve iflâs takip talepleri açısından da belirtilen "tüm" sıfatının geçerli olduğunun kabulü gerekir. Bu çerçevede, yalnızca İcra ve İflâs Kanunu'nda düzenlenen takipler değil, diğer kanunlarda düzenlenen icra ve iflâs takiplerinin de başlatılamayacağının kabulü gerekir. Örneğin, 7155 sayılı Kanun kapsamındaki takiplerin de başlatılması mümkün değildir.

Bu noktada kamu hukukuna ilişkin olarak 6183 sayılı Kanun kapsamındaki takiplerin akıbetleri düşünülebilir. Kanun koyucu takiplerin durması açısından "tüm" icra takiplerinden söz etmektedir. Ancak, yeni icra ve iflâs takipleri açısından ise "takip taleplerinin alınmaması"ndan söz etmektedir. Kanunun lafzı dikkate alındığında, 6183 sayılı Kanun açısından bu anlamda bir takip talebinden söz edilemeyeceği için ilgili takiplerin başlatılabileceği düşünülebilirr ${ }^{14}$. Kanaatimizce burada zikredilen düzenlemenin lafzı ve amacı birlikte değerlendirilerek bir sonuca varılmalıdır. Yukarıda belirtildiği üzere, takip hukuku açısından alınan tedbirler borçlunun ekonomik mahvını engellemeye yöneliktir. Bu çerçevede amaç, borçluya karşı yapılacak bütün takiplere mâni olmaktır. Nitekim duracak takipler belirlenirken açıkça "tüm” takiplerden söz edilmiştir. Ayrıca kanun koyucu yalnızca 2004 sayılı İcra ve İflâs Kanuna dayalı takipleri kapsamamakta, yukarıda incelendiği üzere, "takip hukukuna ilişkin diğer kanunlardan" söz etmektedir. Düzenlemenin lafzı ve

\footnotetext{
Nitekim öğretide 2004 sayılı İcra ve İflâs Kanunu'nun açıkça belirtilmiş olmasına rağmen kamu alacaklarına ilişkin temel kanunun belirtilmemesi nedeniyle 6183 sayılı Kanuna göre yapılacak takiplerin düzenleme kapsamında olmadığı, bunun da hak aramada eşitliği zedelediği ve birçok temel hakkı ihlal edeceği savunulmaktadır. Bu yönde bkz Atalay ve Özekes, (n 7) https://blog.lexpera.com.tr/7226-sayili-kanun-ile-cumhurbaskanligi-karari-neticesinde-ortaya-cikan-sorunlar Erişim Tarihi 18 Haziran 2020.
} 
amacının birlikte değerlendirilmesi halinde, 6183 sayılı Kanuna dayalı takiplerin de başlatılamayacağının kabulü uygun olur ${ }^{15}$. Aksi kabulde, zaten hak arama özgürlüğü sınırlanmış alacaklının, borçlunun kamuya olan borçları sebebiyle malvarlığının ortadan kalkması üzerine alacağını elde edememesi tehlikesi ortaya çıkar ki böyle bir düzenleme hakkın özüne dokunması sebebiyle Anayasa’ya da aykırı olur. Ancak tereddütlerin giderilmesi adına 6183 sayılı Kanun'un da açıkça zikredilmesi isabetli olurdu.

İcra ve iflâs takipleri açısından alınan tedbirler ile (nafaka alacakları hariç) yalnızca takipler durdurulmuştur. Dolayısıyla, mevcut takipler bulundukları aşamada derdest kalmaya devam eder. Örneğin, daha öne ödeme emri gönderilerek kesinleşen takip, bu aşamada kalmaya devam eder, alacaklı haciz talep edemez. Keza haciz gerçekleştirilmişse, satış istenemez, ancak malvarlığı değerleri haciz olarak kalmaya devam eder.

\section{Takip İşlemleri Açısından Alınan Tedbirler}

7226 sayılı Kanun'un Geçici 1'inci maddesinin birinci fikrasının b bendinde, yalnızca icra takiplerinin durmasını düzenlenmemiş, ayrıca bu süre içerisinde taraf ve takip işlemlerinin de yapılamayacağı belirtilmiştir. Esasen icra takiplerinin durmasına ilişkin tedbir, cebri icra işlemlerinin de yapılmasına manidir ${ }^{16}$. Ancak kanun koyucu, olağan tatil ve talik hallerinden de farklı olarak bütün takip işlemlerinin öngörülen süreç boyunca yapılmasını engellemiştir. Başka bir anlatımla, sadece icra dairesi tarafından gerçekleştirilecek icra takip işlemleri değil, bir bütün olarak takibe dair bütün işlemler, taraflarca gerçekleştirilecekler de dahil engellenmiştir. Esasen kavram tercihi yönünden mevcut düzenlemenin eleştirisi bir tarafa, takip hukuku alanında zaman zaman tereddütlere sebep olan bir işlemin icra takip işlemi olup olmadığg konusundaki tartışmaya, mevcut düzenleme açısından ihtiyaç kalmamıştır. Zira düzenleme ile ayrım yapılmaksızın bütün takip işlemlerinin, ister taraflar isterse icra dairesi tarafından yapılsın, önüne geçilmiştir. Örneğin, mevcut düzenleme uyarınca, borçlunun da ödeme emrine itiraz edebilmesi mümkün değildir.

7226 sayılı Kanun'un Geçici 1'inci maddesinin birinci fikrasının b bendi kapsamında, 22.03.2020 tarihi ile 15.06.2020 tarihleri arasında satış talebinde bulunulması ve artırmanın yapılması, ihale kararı alınması mümkün değildir. $\mathrm{Bu}$ kapsamda henüz ilan yapılmamış artırma işlemleri açısından da artırmaya hazırlık işlemlerinin durma süresinden sonra, İcra ve İflas Kanunu’nun öngördüğü şekilde (şartnamenin hazırlanması, taşınmazlar açısından ilgililere tebliğ, ilanın şekli)

\footnotetext{
Pekcanıtez ve Erişir, (n 8) https://legal.com.tr/blog/genel/koronavirus-covid-19-salginina-karsi-alinan-medeni-usûl-veicra-iflâs-hukukunu-ilgilendiren-onlemler Erişim Tarihi 18 Haziran 2020.

16 Pekcanitez ve Erişir, (n 8) https://legal.com.tr/blog/genel/koronavirus-covid-19-salginina-karsi-alinan-medeni-usûl-veicra-iflâs-hukukunu-ilgilendiren-onlemler Erişim Tarihi 18 Haziran 2020.
} 
yapılması gerekir ${ }^{17}$. Ancak, daha önce ilan edilen artırmanın öngörülen tarih aralığına rastlaması halinde, nasıl hareket edileceği konusunda bir tereddüt hasıl olabilirdi. Kanun koyucu, 7226 sayılı Kanun’un Geçici 1'inci maddesinin üçüncü fikrasında, artırmanın gerçekleşmesine ilişkin özel bir düzenleme yapmıştır ${ }^{18}$. Buna göre, icra ve iflâs daireleri tarafından mal veya haklara ilişkin olarak ilan edilmiş olan artırma gününün durma süresi içinde (22.03.2020 - 15.06.2020) kalması halinde, bu mal veya haklar için durma süresinden sonra yeni bir talep aranmaksızın icra ve iflâs dairelerince satış günü verilir. Bu durumda satış ilanı sadece elektronik ortamda yapılır ve ilan için ücret alınmaz. Dolayısıyla, birinci veya ikinci artırma tarihinin 22.03.2020 - 15.06.2020 tarihleri arasında kalması durumunda, söz konusu artırma gerçekleştirilemez; ancak yeni artırma için taraflardan tekrar talep aranmayacağı gibi daha önce nasıl gerçekleştirildiğinden bağımız olarak ilan da, herhangi bir ücret alınmaksızın yalnızca elektronik ortamda yapılır. Kanun koyucu artırma ilanının elektronik ortamda yapılmasıyla yetinileceğini öngördügünden, taşınmazlar ilişkin İcra ve İflâs Kanunu'nun 127 'nci maddesinde öngörülen ilgililere tebliğe de ihtiyaç yoktur ${ }^{19}$. Durma süresinden önce birinci artırma gerçekleştirilmiş olmasına rağmen kanunda öngörülen şartları sağlayan bir teklif bulunmadığı için ikinci artırmanın yapılması gereken durumlarda da, ikinci artırma tarihinin durma süresi rastlaması halinde, bu artırma yapılamayacak; durma süresinin geçmesinden sonra artık yalnızca ikinci artırma için yukarıda öngörülen usûlde ilan yapılır. Başka bir anlatımla, birinci artırma geçerliliğini korur. Bu konuda yaşanan bir tereddüt ve UYAP'1n yalnızca ikinci artırma gününe izin vermemesi sebebiyle Hopa Cumhuriyet Başsavcılığ1 tarafından yazı üzerine, Adalet Bakanlığı'nın 18.06.2020 tarihli cevabi yazısında da yalnızca ikinci artırma için yeni tarihin ilan edileceği belirtilmiştir.

Artırma işlemlerine ilişkin bir tereddüt de İcra ve İflâs Kanunu'nun 113'üncü maddesinin ikinci fikrasındaki düzenleme sebebiyle yaşanabilir. Buna göre, muhafazası masraflı ve değeri süratle düşen malların satılmasına icra dairesi tarafından re'sen satılmasına karar verilebilir. Bu noktada tereddüt, durma süresi içerisinde bu yönde bir karar alınıp alınamayacağı hususundadır. Düzenlemenin

17 Uğur, Bulut, ‘7226 Sayılı Kanun’un İcra Hukukundaki Satış ve Paraların Ödenmesi İşlemlerine Etkisi’, (Lexpera Blog, 18.05.2020) https://blog.lexpera.com.tr/7226-sayili-kanunun-icra-hukukundaki-satis-ve-paralarin-odenmesi-islemlerineetkisi Erişim Tarihi 18 Haziran 2020.

18 Esasen söz konusu düzenlemeden önce 2279 sayılı Cumhurbașkanlığı kararı üzerine Adalet Bakanlığı tarafindan hazırlanan 86420598-296/2543 sayıl1 görüş yazısında, "İcra ve iflâs daireleri tarafindan satış günü verilerek ilan edilmiş mal ve haklara ilișkin elektronik veya fiziki arttırmanın günlerinin durdurma tarihleri içinde kalması hallerinde, durdurma kararının bitiminden itibaren yeni satış günü verileceği, bu durumda satış ilanının İcra ve İlâs Kanununun 114üncü maddesinin ikinci fikrasındaki ilkeler doğrultusunda tarafların menfaatleri gözetilerek en az masrafla katılımcı saylsını en çok arttıracak vasıta ile ilanın yapılmasının uygun olacağı, daha önce masrafi verilip ilan yapılmış olması nazara alınarak alacaklı ve borçluya ek masraf yüklemeyecek şekilde ilanın yapılmasına özen gösterilerek, durma kararı nedeni ile satış işlemleri gerçekleşmeyen mal ve haklar yönünden durma sürecinden sonra yapılacak ilanların UYAP İcra Malları e-Satış Portalında yapılmasının uygun olacağı" belirtilmişti. Ele aldığımız kanuni düzenleme, ana hatları ile ilgili görüşü esas almış, yalnızca ilanın yapılması konusunda takdir yetkisini kaldırarak elektronik ortamda yapılması öngörülmüş, ayrıca yeni satış günü için talep aranmayacağı belirtilmiştir.

19 Bulut, (n 19) https://blog.lexpera.com.tr/7226-sayili-kanunun-icra-hukukundaki-satis-ve-paralarin-odenmesi-islemlerineetkisi Erişim Tarihi 18 Haziran 2020. 
lafzı dikkate alındığında, bir takip işlemi olması sebebiyle, İcra ve İflâs Kanunu'nun 113'üncü maddesinin ikinci fıkrası kapsamında da satış kararının alınamaması icap eder. Ancak söz konusu hükmün takibin her iki tarafının da menfaatini koruma amacı dikkate alındığında, bu yönde alınacak bir satış kararının 7226 sayılı Kanun'un Geçici 1'inci maddesinin birinci fikrasının b bendi ile korunmak istenen menfaatleri ihlal etmeyeceği değerlendirilmelidir. Ayrıca İcra ve İflâs Kanunu'nun 119'uncu maddesinin birinci fikrasının dördüncü bendi uyarınca bu nitelikteki malların pazarlık suretiyle satışına karar verilebilir. Benzer şekilde, taraf menfaatleri dikkate alınarak bu nitelikteki mallar için satı̧s işlemleri yapılabilmelidir.

Durma süresinden önce artırma gerçekleşmiş ve ihale kararı kesinleşmiş, ancak mal henüz alıcıya teslim edilmemişse, bu durumda icra dairesinin malı teslim edip gerekirse alıcı adına tescili talep edip edemeyeceği Kanunda düzenlenmemiştir. Esasen bir takip işlemi olmayan tescil ve teslimin bu süreçte de gerçekleştirilebilmesi gerekir. Düzenlemenin amacı da dikkate alındığında, aksi bir yorum yapılmasına ihtiyaç bulunmadığ 1 da görülmektedir. Adalet Bakanlığ 1 tarafından Kanun Resmî Gazete'de yayınlanmadan önce yayınlanan görüş yazısında, durma kararı öncesinde ihalesi yapılıp kesinleşen ihalelerin tescil işleminin yapılabileceği, teslim işlemlerinin yapılmasının ise alınan tedbirlere ve durdurma kararının amacına aykirllı oluşturmayacak şekilde icra müdürlüklerince takdir edilebileceği belirtilmiştir.

Kanun koyucu durma süresi içerisinde icra dairesine rızaen ödeme yapılabileceği kabul etmiştir. Ancak söz konusu paranın alacaklıya ödenip ödenemeyeceği konusunda bir açıklık Kanunda yer almamaktadır. İcra dairesince alacaklıya gerçekleştirilecek ödeme bir icra takip işlemi değildir ${ }^{20}$. Ancak yukarıda açıklandığ üzere, kanun koyucunun bütün takip hukukuna ilişkin bütün işlemleri kural olarak engellediği görülmektedir. Alacaklıya yapılacak ödemenin de bu kapsamda olup olmadığ 1 konusunda tereddüt edilebilir. Kanaatimizce icra dairesine rızaen yapılan ödeme üzerine elde edilen paranın, paranın alacaklıya ödenebilmesine yönelik rızayı da kapsadığının kabulü gerekir ${ }^{21}$. Zira takip hukukuna ilişkin alınan tedbirlerin temel saikinin ekonomik mahvın önüne geçmek olduğu yukarıda belirtilmiştir. Bu çerçevede, alacaklının alacağına kavuşmasının da ilgili düzenleme ile engellendiği düşünülemez. İcra dairesinin hesabında hiç kimsenin istifade edemediği para, yalnızca ekonomik açıdan zarar verecektir. Kendisine karşı cebri işlem yapılamayacak borçlunun, buna rağmen icra dairesine ödemede bulunmakta olması, bu paranın alacaklıya verilmesine ilişkin rızası bulunduğunu da göstermektedir. Keza kesinleșen ihale kararı sebebiyle alıcının yapmış olduğu

20 Baki Kuru, İcra ve İflâs Hukuku (3. Bası, Evren 1988) C I, 138; Bilge Umar, İcra ve İflâs Hukukunun Tarihi Gelişmesi ve Genel Teorisi (1. Bası, Ege Üniversitesi İktisadi ve Ticari İlimler Fakültesi Yayınları 1973) 186.

${ }_{21}$ Pekcanıtez ve Erişir, (n 8) https://legal.com.tr/blog/genel/koronavirus-covid-19-salginina-karsi-alinan-medeni-usûl-veicra-iflâs-hukukunu-ilgilendiren-onlemler Erişim Tarihi 18 Haziran 2020; Bulut, (n 19) https://blog.lexpera.com.tr/7226sayili-kanunun-icra-hukukundaki-satis-ve-paralarin-odenmesi-islemlerine-etkisi Erişim Tarihi 18 Haziran 2020. 
ödemelerin de alacaklıya ödenebilmesi gerekir ${ }^{22}$. Ayrıca yukarıda sözü edilen Adalet Bakanlığ 1 görüşünde de, dosya kapsamına göre sıra cetveli yapılmasını gerektirmeyen ve borçlu ya da üçüncü kişilerin haklarının ihlal edilmeyeceğinin anlaşıldiğı durumlarda paraların alacaklılarına ödenebileceği belirtilmiştir. Ancak uygulamada icra dairelerinin genel olarak taraf ve takip işlemlerinin durmuş olması nedeniyle başka icra dosyalarından haciz talep ve uygulama işlemlerinin yapılamadığı; bu nedenle, ödeme yapılan takipteki alacaklıdan alacaklı olan üçüncü kişilerin ilgili dosya alacağına haciz talep etmek isteyebilecekleri ama haciz işlemleri durdurulduğu için bu hacizlerin talep edilememiş ve uygulanamamış olabileceği ve bu durumda dosya alacağının ödenmesinin haciz talep edemeyen bu muhtemel üçüncü kişilerin haklarını ihlal edebileceği gibi bir gerekçesiyle ödeme yapmaktan kaçındıkları belirtilmektedir ${ }^{23}$.

7226 sayılı Kanun'un Geçici 1'inci maddesinin üçüncü fikrasının b bendinde, taraflardan birinin, diğer taraf lehine olan işlemlerin yapılmasını isteyebileceği düzenlenmiştir. Dolayısıyla, yukarıda yer verilen ve yapılamayacağı belirtilen bütün taraf ve icra takip işlemleri açısından, işlemin aleyhine olan tarafın talep etmesi halinde, söz konusu işlemin gerçekleştirilmesi gerekir. Örneğin, borçlunun mallarının haczedilmesini talep etmesi halinde, durma süresi içerisinde de haczin gerçekleştirilmesi mümkündür. Keza borçlunun taahhütte bulunması, alacaklının mevcut haczin kaldırılmasını istemesi durumunda, ilgili işlemin gerçekleştirilmesi gerekir. $\mathrm{Bu}$ kapsamda, borçlunun haczedilmiş malların paraya çevrilmesini istemesi (İK m. 113/I), kendi borcunun ödenmesini sağlaması yanında, alacaklı lehine de sonuç doğurduğundan, bu yönde bir talepte bulunulması halinde, satışın gerçekleştirilmesi gerekir ${ }^{24}$. Ayrıca, tarafların anlaşmaları durumunda, diğer tarafın lehine olan işlemlerin yapılabilmesine imkân tanıyan bu hüküm sebebiyle, anlaşmaya konu söz konusu işlemin durma süresi içerisinde de yapılabilmesi gerekir ${ }^{25}$.

\section{Takipler ve Takip İşlemleri Açısından Alınan Tedbirlerin Üçüncü Kişilere Etkisi}

7226 say1lı Kanun'un Geçici 1'inci maddesinin birinci fikrasının b bendinde, yalnızca "taraf ve takip işlemlerinin" yapılamayacağı düzenlenmektedir. Bu noktada, takip içerisinde üçüncü kişilere karşı veya üçüncü kişilerce gerçekleştirilecek işlemlerin, durma süresince yapılıp yapılmayacağı sorunu ortaya çıkmaktadır.

\footnotetext{
22 Pekcanıtez ve Erişir, (n 8) https://legal.com.tr/blog/genel/koronavirus-covid-19-salginina-karsi-alinan-medeni-usûl-veicra-iflâs-hukukunu-ilgilendiren-onlemler Erişim Tarihi 18 Haziran 2020.

23 Bulut, (n 19) https://blog.lexpera.com.tr/7226-sayili-kanunun-icra-hukukundaki-satis-ve-paralarin-odenmesi-islemlerineetkisi Erişim Tarihi 18 Haziran 2020.

24 Atalay ve Özekes, (n 7) https://blog.lexpera.com.tr/7226-sayili-kanun-ile-cumhurbaskanligi-karari-neticesinde-ortayacikan-sorunlar Erişim Tarihi 18 Haziran 2020.

25 Atalay ve Özekes, (n 7) https://blog.lexpera.com.tr/7226-sayili-kanun-ile-cumhurbaskanligi-karari-neticesinde-ortayacikan-sorunlar Erişim Tarihi 18 Haziran 2020.
} 
İlk olarak, kanun koyucu yalnızca işlemlerin yapılmaması değil, genel olarak takiplerin de duracağını düzenlediğinden, durma süresi içerisinde icra dairesi tarafından üçüncü kişiye karşı da bir işlem yapılabilmesi mümkün değildir. Örneğin, durma süresinde üçüncü kişiye İcra ve İflâs Kanunu'nun 89'uncu maddesine göre haciz ihbarnamesi gönderilmesi mümkün değildir.

İkincisi, takip içerisinde üçüncü kişi tarafindan gerçekleştirilecek işlemlere dair süreler, 7226 sayılı Kanun'un Geçici 1'inci maddesinin birinci fikrasının b bendinde ayrım yapılmaksızın İcra ve İflas Kanunu'nda düzenlenen süreler olduğundan 22.03.2020 itibariyle durmuştur. Örneğin, üçüncü kişinin istihkak iddiasında bulunması veya haciz ihbarnamesi üzerine (22.03.2020 tarihinden önce gönderilen) itiraz süresi bu kapsamdadır.

Bu noktada tartışmalı olan bir husus, maaş ve ücret hacizleri sebebiyle kesintilerin, durma sürecinde de devam edip etmeyeceği noktasındadır. Durma süresine haciz işlemi yapılamayacağı için, bu süre içerisinde maaş veya ücret haczi için üçüncü kişiye ihbarname gönderilmesi de mümkün değildir. Ancak, durma sürecinden önce gerçekleştirilen haciz işleminin gereği olarak, yine durma tarihinden önce (22.03.2020) gönderilen maaş veya ücret kesintisine ilişkin ihbarnamenin gereğinin durma süresince üçüncü kişi tarafından yerine getirilip getirilmeyeceği belirlenmelidir. Atalay/Özekes, takiplerin tamamen durmuş olması ve bu süre içerisinde muhafaza tedbirlerinin de alınamayacak olması karşısında, maaş kesintilerinin durma süresince devam etmesinin çelişkili olacağını savunmaktadır ${ }^{26}$. Buna karşılık, Pekcanıtez/ Erişir, süreç içerisinde de ödemelerin devam etmesi gerektiğini, zira durmaya rağmen mevcut hacizlerin varlığını muhafaza ettiğini, kesintinin durdurulmasının ise haczin kaldırılması sonucunu doğuracağını belirtmektedir ${ }^{27}$. Adalet Bakanlı̆̆ı'nın Hazine ve Maliye Bakanlığına hitaben gönderdiği 02.04.2020 Tarih ve 864205598300/2678 Sayılı yazısında da, 22.03.2020 tarihinde evvel haciz tutanăg ile haczine karar verilmiş maaş ve ücretler için kesintilere devam edilmesine ve birden fazla icra dosyasının bulunması halinde, bir dosyadan kesintinin bitmesi halinde sırası gelen icra dosyaları için de maaş haciz kesintisine devam edilmesi gerektiğine ilişkin görüş bildirilmiştir. Kanaatimizce, düzenlemenin amacının, içerisinde bulunulan olağan dışı durum dikkate alındığında, bütün takip ve takip işlemlerini durdurmak isteyen kanun koyucunun, maaş ve ücret hacizlerine ilişkin kesintilere devam edilmesi olduğunu kabul etmek isabetli görünmemektedir. Getirilen düzenlemelerin temelde ekonomik olarak borçluyu koruyucu nitelikte olduğu ve bu süreç içerisinde hayatını devam ettirmesine matuf olduğu dikkate alındığında, niteliği gereği muhafaza tedbiri

\footnotetext{
26 Atalay ve Özekes, (n 7) https://blog.lexpera.com.tr/7226-sayili-kanun-ile-cumhurbaskanligi-karari-neticesinde-ortayacikan-sorunlar Erişim Tarihi 18 Haziran 2020. Aynı yönde bkz Adnan Deynekli, '7226 Sayılı Kanunla Yapılan Düzenlemenin Sürelere Etkisi Yönünden Değerlendirme' (e-uyar 01.04.2020) < https://app.e-uyar.com/blog/index/478d6362-2806-49bea6c2-89976b382794> Erişim Tarihi 22 Ağustos 2020.

27 Pekcanitez ve Erişir, (n 8) https://legal.com.tr/blog/genel/koronavirus-covid-19-salginina-karsi-alinan-medeni-usûl-veicra-iflâs-hukukunu-ilgilendiren-onlemler Erişim Tarihi 18 Haziran 2020.
} 
olduğu belirtilen maaş kesintilerinin devam edeceğini kabul etmek, düzenlemenin amacı ile bağdaşmamaktadır. Kaldı ki maaş ve ücretlere ilişkin kesinti takip borçlusu yönünde muhafaza tedbiri niteliğinde olmasına rağmen, üçüncü kişi açısından esasen bir icra takip işlemidir. Dolayısıyla, Kanun kapsamında maaş ve ücret kesintilerinin de durduğunun kabulü gerekir. Bu süreçte kesintinin durması halinde, haczin de kalkmış olacağı değerlendirmesine de katılamıyoruz. Zira bu süreçte de haciz varlığını koruyacaktır; ancak bir muhafaza tedbiri olan kesintiler durma süresince adeta askıda kalacak, daha sonra ayrıca bir işleme gerek kalmaksızın mevcut hacizlere ilişkin kesintiye devam edilecektir ${ }^{28}$. Benzer şekilde birer muhafaza tedbiri olarak İcra ve İflâs Kanunu'nun çeşitli hükümlerinde (Örneğin İ̈K m. 92/III veya 150/b) düzenlenen kiracıların kira bedellerini icra dairesine ödemesine dair hükümler de bu süreçte askıdadır. Durma süresi boyunca ödemelerin kiralayana yapılması uygun olur ${ }^{29}$.

\section{C. İhtiyati Haciz Açısından Alınan Tedbirler}

Alacaklının, rehinle temin edilmemiş ve vadesi gelmiş bir para alacağının zamanında ödenmesini güvence altına almak için mahkeme kararı ile borçlunun malvarlığına geçici olarak el koymasına ihtiyati haciz denir.

İhtiyati haczin fonksiyonu, icra takibine başvurulması halinde ödeme veya icra emrinin kesinleşip haciz aşamasına geçilmesinin belirli bir zamanı gerektirmesi nedeni ile, bu dönemde alacaklının alacağının teminat altına alınmasıdır. Borçlunun borcunu zamanında ödeyemeyeceğini düşünen alacaklı, önce borçlunun mallarını ihtiyaten haczettirmekte daha sonra ise dava açmakta veya icra takibi yapmaktadır.

Borçlunun mallarını ihtiyaten haczettirmek isteyen alacaklı, öncelikle mahkemeye başvurarak ihtiyati haciz kararı almalıdır. Alacaklının başvurusu üzerine, mahkeme ihtiyati haciz talebini basit yargılama usûlüne göre inceler (HMK m. 316, I-c). Kanunda öngörülen şartların mevcut bulunduğunun tespit edilmesi halinde, mahkemece ihtiyati haciz kararı verilir.

7226 say1lı Kanun'un Geçici 1'inci maddesi ile ihtiyati haciz talep edilmesi ve hatta mahkemece ihtiyati haciz kararı verilmesi engellenmemiştir. Her ne kadar sürelerin işlemesi durmuş olsa da, ihtiyati haciz kararına karşı itiraz edilebilmesi ve istinaf kanun yoluna başvurulabilmesi mümkündür. Ancak kanun koyucu, durma süresi boyunca ihtiyati haciz kararının icra ve infazının mümkün olmadığını düzenlemiştir. İhtiyati haciz kararının icra edilebilmesi mümkün olmadığı için, ihtiyati haczi tamamlayan merasimin gereği olarak haczin tatbikinden itibaren dava açılması veya icra takibi

\footnotetext{
${ }_{28}$ Muhammet Özekes, ‘7226 Sayılı Kanunun (ve IİK m. 330’un) Açık Hükmü ile Açık Yargıtay Kararlarına Rağmen Adalet Bakanlığı İcra İşleri Daire Başkanlığının Maaş Kesintilerine İlişkin Görüşü Hukuka, Kanuna ve Yargıtay İçtihatlarına Açıkça Aykırıdır', (Lexpera Blog 18.04.2020) https://blog.lexpera.com.tr/adalet-bakanligi-icra-isleri-daire-baskanligininmaas-kesintilerine-iliskin-gorusu-hukuka-aykiridir Erişim Tarihi 18 Haziran 2020.

29 Deynekli, (n 28), https://app.e-uyar.com/blog/index/478d6362-2806-49be-a6c2-89976b382794 Erişim Tarihi 22 Ağustos 2020.
} 
başlatılmasına ilişkin (yedi gün içerisinde) süre de işlemeye başlamayacaktır. Ancak 22.03.2020 tarihinden önce ihtiyati haciz kararı tatbik edilmişse ve yedi günlük süre henüz dolmamışsa, 22.03.2020 itibariyle tamamlayıcı merasime ilişkin bu süre de duracaktır. Dolayısıyla, her iki ihtimalde de ihtiyati haciz kararının kendiliğinden kalkması söz konusu olmaz ${ }^{30}$.

\section{Konkordato Açısından Alınan Tedbirler}

7226 sayılı Kanun’un Geçici 1'inci maddesinin üçüncü fikrasının c bendinde, konkordato mühletinin alacaklı ve borçlu bakımından sonuçlarının, durma süresince de devam edeceği düzenlenmiştir. Kanun koyucu konkordato mühleti verilmesinin yalnızca alacaklı ve borçlu bakımından sonuçlarına atıf yaptığ 1 için, mühlet verilmesi ile ortaya çıkan diğer sonuçların akıbeti konusunda tereddüt doğmaktadır ${ }^{31}$.

7226 sayılı Kanun ile icra takipleri açısından alınan tedbirler, konkordato mühletinin verilmesinin yaratmış olduğu etkiden geniş ve kapsamlıdır. Zira mühlet içerisinde birinci sıradaki alacaklıların takip yapması mümkün iken, 7226 sayılı Kanun ile yalnızca nafaka alacakları istisna tutulmuştur. 7226 sayılı Kanun ile getirilen "alacaklı bakımından sonuçlarının” devam edeceğine ilişkin hükmün, lafzı dikkate alınarak değerlendirilecek olursa, diğer bütün borçlular için takip yasağı varken, mühlet içerisinde mevcut bir projeyi gerçekleştirmeye çalışan borçluya karşı birinci sıradaki alacaklıların takip yapmasının mümkün olduğu gibi bir sonuç çıkacaktır. Temel amacı borçlunun hazırlamış olduğu konkordato projesi ile borçlunun ekonomik olarak faaliyetlerine devam etmesini sağlamak olan konkordato mühleti verilmesinin, mevcut şartlarda bütün borçluların ekonomik mahvını engelleyen tedbir kapsamı dışında bırakılması, 7226 sayılı Kanun'un amacı ile bağdaşmaz. Durma sürecinin ortaya çıkardığı mevcut ekonomik şartlar dikkate alındığında, borçlunun bu süreçte beklenen faydayı sağlayamayacağı ortadadır. Keza bu süreç içerisinde mühlet içerisinde yapılabilecek bazı işlemlerin (örneğin alacaklılar toplantısı gibi) sağlık veya sokağa çıkma yasakları sebebiyle gerçekleştirilememesi mümkündür. Bu kapsamda, durma süresi boyunca mühlet kararının takip yasaklarına ilişkin hükümlerinin askıda olduğunun kabulü isabetli olacaktır ${ }^{32}$. Bunun dişında, konkordato mühleti verilmesiyle ortaya çıkan hukuki durum varlığını muhafaza etmeye devam eder.

Konkordato geçici veya kesin mühletine ilişkin süreler de İcra ve İflas Kanunu'nda düzenlenen sürelerden olduğundan, 22.03.2020 - 15.06.2020 tarihleri arasında

\footnotetext{
30 İhtiyati tedbirlere göre farklılık açısından bkz Atalı ve Erdoğan, (n 13), 39-40.

31 Atalay ve Özekes, (n 7) https://blog.lexpera.com.tr/7226-sayili-kanun-ile-cumhurbaskanligi-karari-neticesinde-ortayacikan-sorunlar Erişim Tarihi 18 Haziran 2020; Pekcanıtez ve Erişir, (n 8) https://legal.com.tr/blog/genel/koronavirus-covid19-salginina-karsi-alinan-medeni-usûl-ve-icra-iflâs-hukukunu-ilgilendiren-onlemler Erişim Tarihi 18 Haziran 2020.

32 Atalay ve Özekes, (n 7) https://blog.lexpera.com.tr/7226-sayili-kanun-ile-cumhurbaskanligi-karari-neticesinde-ortayacikan-sorunlar Erişim Tarihi 18 Haziran 2020; Pekcanıtez ve Erişir, (n 8) https://legal.com.tr/blog/genel/koronavirus-covid19-salginina-karsi-alinan-medeni-usûl-ve-icra-iflâs-hukukunu-ilgilendiren-onlemler Erişim Tarihi 18 Haziran 2020.
} 
duracaktır. Dolayısıyla 22.03.2020 tarihi itibariyle tamamlanmasına onbeş günden az kalmış süreler, 15.06.2020 tarihinden itibaren onbeş gün uzamış sayılarak 30.06.2020 tarihinde sona erecektir. 22.03.2020 tarihi itibariyle tamamlanmasına onbeş günden fazla kalan ancak nihayeti durma süresi içerisinde kalan mühlet süreleri için ise 15.06.2020 tarihinden itibaren kalan süre kadar ekleme yapılacaktır. Mühletin nihayeti durma süresinden sonraya tekabül etmekte ise, durma süresi kadar bir ilavenin sürenin sonuna yapılması gerekecektir ${ }^{33}$. Ayrıca konkordatoya ilişkin olarak kanunda düzenlenen diğer süreler de (İIK m. 290/III, İ̈K m. 301, İ̈K m. 302/V, İIK m. 302/VI, İIK m. 304/II gibi) 22.03.2020 - 15.06.2020 tarihleri arasında duracaktır.

Son olarak durma süresi içerisinde yeni konkordato talebinin mümkün olup olmadığ1 değerlendirilmelidir. Yukarıda ifade edildiği üzere, 7226 sayılı Kanun ile borçlular bakımından getirilen tedbirler, konkordato mühleti verilmesinin sağlayacağ 1 tedbirlerden daha kapsamlıdır. Bu çerçevede, durma süresi içerisinde konkordato mühleti verilmesinin talep edilmesinde hukuki yarar bulunmadığının kabulü gerekir ${ }^{34}$.

\section{Sonuç}

Covid-19 salgını ve bununla mücadele kapsamında alınan önlemler hem ekonomik yaşamı hem de yargılama faaliyetlerini olumsuz etkilemektedir. Bu kapsamda, salgının yaratacağı ekonomik etkilerin borçlular üzerinde yaratacağı olumsuz sonuçların bertaraf edilmesi amaciyla, takip hukuku açısından - yargılama hukukundan farklı olarak - adeta bir kül olarak cebri icra faaliyetlerinin durdurulması yoluna gidilmişsir. Durma süresinin tamamlanması ile birlikte özellikle cebri icra taleplerinde bir yığılma olması kaçınılmazdır. 15.06.2020 tarihinden sonra gerçekleşecek yoğun talebin, tedbirler ile ekonomik açıdan umulan bütün faydayı bertaraf etme tehlikesi bulunmaktadir ${ }^{35}$.

\footnotetext{
Hakem Değerlendirmesi: Dış bağımsız.

Çıkar Çatışması: Yazar çıkar çatışması bildirmemiştir.

Finansal Destek: Yazar bu çalışma için finansal destek almadığını beyan etmiştir.

Peer-review: Externally peer-reviewed.

Conflict of Interest: The author has no conflict of interest to declare.

Grant Support: The author declared that this study has received no financial support.
}

\footnotetext{
33 Bu konuda ayrıntılı hesaplamalar için bkz Müjgan Tunç-Yücel, '7226 sayılı Kanun ile Cumhurbaşkanlığının 2480 sayılı Yarg1 Alanındaki Hak Kayıplarının Önlenmesi Amacıyla Getirilen Durma Süresinin Uzatılmasına Dair Kararı Uyarınca Sürelerin Durmasının Konkordato Sürelerine Etkisi', (Lexpera Blog 11.05.2020) https://blog.lexpera.com.tr/7226-sayilikanun-ile-cumhurbaskanliginin-2480-sayili-karari-uyarinca-surelerin-durmasinin-konkordato-surelerine-etkisi Erişim Tarihi 18 Haziran 2020.

34 Atalay ve Özekes, (n 7) https://blog.lexpera.com.tr/7226-sayili-kanun-ile-cumhurbaskanligi-karari-neticesinde-ortayacikan-sorunlar Erişim Tarihi 18 Haziran 2020; Pekcanıtez ve Erişir, (n 8) https://legal.com.tr/blog/genel/koronavirus-covid19-salginina-karsi-alinan-medeni-usûl-ve-icra-iflâs-hukukunu-ilgilendiren-onlemler Erişim Tarihi 18 Haziran 2020.

35 Bu konuda bazı öneriler için bkz Oğuz Atalay, 'COVID-19 Salgını Sebebiyle Gerçekleşen Takip Tatili Sonrasına İlişkin Bazı Düşünceler ve Öneriler’, (Lexpera Blog 21.05.2020) https://blog.lexpera.com.tr/covid-19-salgini-sebebiyle-gerceklesentakip-tatili-sonrasina-iliskin-bazi-dusunceler-ve-oneriler Erişim Tarihi 19 Haziran 2020.
} 


\section{Bibliyografya/Bibliography}

Altay S ve Eskiocak A, Konkordato ve Yeniden Yapılanma Hukuku, (4. Bas1, Vedat 2018).

Arslan AS, ‘Covid-19 Salgını Sebebiyle İcra Takiplerine İlişkin Düzenlemelerin Değerlendirilmesi’, (2020), 33(148), TBBD 197-234.

Atalay O ve Özekes M, '7226 Sayılı Kanun ile İcra ve İflâs Kanunu m. 330 Hükmünü Uygulayan Cumhurbaşkanlığı Kararı (2279 Sayılı) Çerçevesinde Ortaya Çıkan Bazı Sorular ve Tartışmalara Cevaplar', (Lexpera Blog, 27.03.2020) https://blog.lexpera.com.tr/7226-sayili-kanun-ilecumhurbaskanligi-karari-neticesinde-ortaya-cikan-sorunlar Erişim Tarihi 18 Haziran 2020.

Atalay O, 'COVID-19 Salgını Sebebiyle Gerçekleşen Takip Tatili Sonrasına İlişkin Bazı Düşünceler ve Öneriler', (Lexpera Blog 21.05.2020) https://blog.lexpera.com.tr/covid-19-salgini-sebebiylegerceklesen-takip-tatili-sonrasina-iliskin-bazi-dusunceler-ve-oneriler Erişim Tarihi 19 Haziran 2020.

Atalı M ve Erdoğan E, 'Covid-19 Salgını Sebebiyle Yapılan Düzenlemelerin Medenî Usûl Hukuku Alanına Yansımaları', iç Muhammet Özekes (ed), Covid-19 Salgınının Hukuki Boyutu Hukukun Tüm Alanlarında Değerlendirmeler (1. Bas1, Oniki Levha 2020).

Bulut U, ‘7226 Sayılı Kanun’un İcra Hukukundaki Satış ve Paraların Ödenmesi İşlemlerine Etkisi’, (Lexpera Blog, 18.05.2020) https://blog.lexpera.com.tr/7226-sayili-kanunun-icra-hukukundakisatis-ve-paralarin-odenmesi-islemlerine-etkisi Erişim Tarihi 18 Haziran 2020.

Deynekli A, '7226 Sayılı Kanunla Yapılan Düzenlemenin Sürelere Etkisi Yönünden Değerlendirme' (e-uyar 01.04.2020) https://app.e-uyar.com/blog/index/478d6362-2806-49be-a6c2$89976 b 382794$ Erişim Tarihi 22 Ağustos 2020.

Kiraz TÖ, 'Fevkalâde Hallerde Mühlet ve Tatil' (2000), 2, Manisa Barosu Dergisi 7-20.

Kuru B, Ícra ve Iflâs Hukuku (3. Bas1, Evren 1988) C I.

Özekes M, ‘7226 Sayılı Kanunun (ve İIK m. 330’un) Açık Hükmü ile Açık Yargıtay Kararlarına Rağmen Adalet Bakanlığı İcra İşleri Daire Başkanlığının Maaş Kesintilerine İlişkin Görüşü Hukuka, Kanuna ve Yargıtay İçtihatlarına Açıkça Aykırıdır', (Lexpera Blog 18.04.2020) https:// blog.lexpera.com.tr/adalet-bakanligi-icra-isleri-daire-baskanliginin-maas-kesintilerine-iliskingorusu-hukuka-aykiridir/ Erişim Tarihi 18 Haziran 2020.

Pekcanıtez H ve Erişir E, 'Koronavirüs (Covid-19) Salgınına Karşı Alınan, Medenî Usûl ve İcra-İflâs Hukukunu İlgilendiren Önlemler', (Legal Blog, 03.06.2020) https://legal.com.tr/ blog/genel/koronavirus-covid-19-salginina-karsi-alinan-medeni-usûl-ve-icra-iflâs-hukukunuilgilendiren-onlemler Erişim Tarihi 18 Haziran 2020

Tunç-Yücel M, '7226 sayılı Kanun ile Cumhurbaşkanlığının 2480 sayılı Yargı Alanındaki Hak Kayıplarının Önlenmesi Amacıyla Getirilen Durma Süresinin Uzatılmasına Dair Kararı Uyarınca Sürelerin Durmasının Konkordato Sürelerine Etkisi', (Lexpera Blog 11.05.2020) https://blog.lexpera.com.tr/7226-sayili-kanun-ile-cumhurbaskanliginin-2480-sayili-karariuyarinca-surelerin-durmasinin-konkordato-surelerine-etkisi Erişim Tarihi 18 Haziran 2020.

Umar B, İcra ve İflâs Hukukunun Tarihi Gelişmesi ve Genel Teorisi (1. Bas1, Ege Üniversitesi İktisadi ve Ticari İlimler Fakültesi Yayınları 1973).

Y1lmaz E, 'Olağanüstü Durumlarda Borçlulara Süre Verilmesi ve İcra Takiplerinin Durdurulması' (1977), IX(1), BATIDER 153-191. 